\title{
State of production, utilization and research of cultivated mushrooms and other edible fungi in Czechoslovakia
}

\author{
MILOSLAV STANĚK
}

\begin{abstract}
STANËK, M. 1978: State of production, utilization and research of cultivated mushrooms and other edible fungi in Czechoslovakia. - Karstenia 18 (suppl.).

The cultivation of the mushrooms Agaricus bisporus, A. bitorquis, and other fung $i$ as Pleurotus astreatus etc. has developed in the last 10 years. Ine production of the cultivated mushrooms is still low $(1200-1500+)$, however, the new plants with a big production capacity are under construction. The fungus pleurotus ostreatus is cultivated by some agricultural establishments. The cultivation of Flammulina velutipes and some species of the genus pleurotus is developing.

A centre for the theoretical research of the cultivated edible fungi is the Institute of Microbiology of the Czechoslovak Academy of Sciences. Mycological Station in Prague selects new strains of the cultivated mushrooms, investigates new composts and new methods for cultivation and protection of cultivated fungi against diseases.
\end{abstract}

M. Stanëk, Institute of Microbiology, Czechoslovak Academy of Sciences, Budejovickä 1083, 14200 Prague 4, Czechoslovakia.

There is a high consumption of edible fungi in Czechoslovakia. In the past the fruit-bodies of edible higher fungi were picked up in woods and sold in large quantities on the market. A great part of the dried and canned edible fungi was assigned for export. Mainly Boletus edulis, Cantharellus oibarius, and other Czechoslovak codex fungi were picked and sold. The purchase of fruit-bodies was organized by the co-operative "Jednota", the main processor was "Mykoprodukta" and the canning was done by other establishments, too. Owing to the social changes the quantity of marketed fungi continually has decreased and at the present time they are mostly picked up only for household consumption.

For this reason the cultivation of the mushroom Agaricus bisporus and other cultivated edible higher fungi has developed in the past 10 years.

The first modern mushroom house was built in Babice in South Moravia (VSD Mykoprodukta) and produces at present 80 tons of fruit-bodies yearly. It utilizes the 3-zone system of cultivation in trays with a low layer of the pasteurized substrate $(10 \mathrm{~cm}$; $\left.40 \mathrm{~kg} / \mathrm{m}^{2}\right)$. Under these conditions the average yield is $9-10 \mathrm{~kg} / \mathrm{m}^{2}$. On this experimental model of a mushroom plant some other small growing centres were built later. Simultaneously some of the Uniform Agricultural Co-operatives have begun to cultivate mushrooms by a modern method on shelves according to the model of Holland mushroom growers. At the present time we have three mushroom plants for the yearly production of 100 tons of mushroom and a lot of small ones. The production of cultivated mushrooms ( $A$. bisporus and A. bitorquis) is still low (1 200-1 500 t); however, new growing plants with larger production capacities are under construction.

In Czechoslovakia various methods are used for compost preparation and mushroom cultivation.Generally horse manure is fermented mostly 12 days in piles, then pasteurized for 24 or 48 hours at $55-60^{\circ} \mathrm{C}$ and conditioned $3-6$ days at $45-50^{\circ} \mathrm{C}$. Pig slurry and other raw materials have been used for mushroom compost in pilot production. The fermentation of the compost "in bulk", i.e. in special tunnels, is very popular at the present time. Special machines of Czechoslovak or foreign origin are used for compost preparation. Various methods based on tray and shelf cultures have been tested and experiences will be taken into consideration in the new big mushroom plants.

The cultivation of other edible fungi including A. bitorquis, Pleurotus ostreatus, P. Cornucopiae, Stropharia rugoso-annulata, etc., is developing Pilot cultures of oyster mushrooms Pleurotus spp. have been founded in southern Slovakia and in some ágricultural co-operatives in Moravia. Wheat straw is mostly used for the cultivation of the oyster mushroom. The substrates are fermented for a short term at the temperature $50-55^{\circ} \mathrm{C}$ and spawned in the trays or in special constructions. Before the fruiting the $P$. ostreatus cultures are mostly cooled to $5-10^{\circ} \mathrm{C}$. The fruit-bodies grow in mushroom houses or in glasshouses under light and at high air humidity. The first cropping flushes are very strong and yields reach $15-30 \%$ of the substrate weight in total.

The cultivation of $S$. rugoso-annulata is popular among amateur gardeners. In this case the cultivation methods are evidently simpler than when cultivating $A$, bisporus. The raw material for preparing nutrient substrates is moist straw; a casing layer may 
not contain much calcium. The cultures are planted into earth (16-20 cm high straw layer) or in polyethylene bags. In a mushroom house in Nový Jičín (Veterinary School, Brno) pilot cultures of Flammula velutipes have been planted.

All the growers are organized in the Section of Mushroom Growing of the Czechoslovak Society of Science and Technology - Society of Agriculture. This society publishes a special journal ('Vẽstník pěstitelu"), arranges periodical meetings, conferences and training courses for the growers.

In Czechoslovakia the cultivation and consumption of mushrooms has increased tenfold during the last decade. The greatest part of cultivated mushrooms is consumed in restaurants and hotels, and processed by the food industry to special salads, cheeses with mushroom, etc. At the present time the demand for mushrooms is higher than its supply, but we hope the situation will improve within the next decade. It is interesting that the utilization of and preparation of meals from cultivated mushrooms differ in our country from the traditional cooking of wild-growing fungi: mushroom salads in mayonnaise, fried mushrooms and other modes are now popular.

The development of edible fungi production in Czechoslovakia was stimulated by research results gained in the Institute of Microbiology and the Mycological Station in Prague and in other institutes.

The Institute of Microbiology of the Czechoslovak Academy of Sciences in Prague is a centre for theoretical research on cultivated edible fungi. A special laboratory in the Department of Experimental Mycology is engaged in the microbial research of nutrient substrates applied in cultivation of edible fungi. Problems of physiology of the higher fungi and possibilities for their cultivation are studied there. The laboratory is co-operating with various mushroom research centres. In other parts of the department the genetic problems in Agrocybe aegerita are studied and collections of higher fungus strains are maintained,in addition to work on other topics including the biochemical activity of fungi.

The work-team of the Mycological Station in Prague solves practical problems in mushroom growing. The Station selects new strains of cultivated mushrooms, investigates new methods for mushroom cultivation and compost preparation, and looks for new ways of plant protection. In addition, the irradiation of mushroom fruit-bodies has been investigated in order to prolong their storage period. The work of the Mycological Station is very useful. It co-operates with the Academy of Sciences and on the other side, has good connections with the growing plants.

Some partial problems are studied at the Brno Veterinary School (is Novf Jičn), at the Research Institute of Distilleries and Canneries in Bratislava, and at the subsidiary of Prague University of Agriculture in Hluboká.

What are the most important results of Czecho- slovak research in the cultivation of edible higher fungi?

The results of research on the microbial aspects of mushroom compost were published recently (Stanĕk 1976) and were compiled in another paper (Staněk 1978). Recent experiments showed that nutrient substrate for the growing of $P$. ostreatus when inoculated with selected strains of bacteria before fermentation yield a larger crop of this fungus.

The mycelium of various $P$. ostreatus strains utilized different sources of nitrogenous and carboneous nutrients. It grew slowest in a nutrient medium without nitrogen. The experiments have proved that the fixation of atmospheric nitrogen by two Pleurotus strains can be as high as 2.6-4 $\mathrm{mg}$ per $1 \mathrm{~g}$ of fermented glucose. However, the results of these experiments have to be verified by other methods (Junková \& Stanĕk 1972).

In other experiments, many strains of higher fungi utilized bacterial polysaccharides (glucanș, gluco-mannans) better than glucose alone.

More others fungal species were cultivated experimentally. A. aegerita grew in a mixture of straw and maize cobs with an addition of sawdust and other materials. The yield of fruit-bodies, which were very tasty, was relatively low. Dr. M. Semerdžieva, C. Sc., however, obtained some new strains which provided higher yields (Esser et al. 1974).

In order to improve mushroom cultivation considerable attention is being paid to obtaining the most productive strains of Agaricus spp., including A. bitorquis, a species not usually cultivated up till now, which is suited for the cultivation at a higher temperature and is virus resistent. At the Mycological Station new strains of Agaricus spp.were obtained after irradiation of germinating spores with gamma rays (Staněk \& Konštantová 1971).

The technology of substrate preparation is undergoing considerable changes, too. A method of composting "in tunnel" has been studied at the Mycological station and introduced in practice with Agaricus and Pleurotus spp. The use of pig slurry for preparing the mushroom compost and of allylisothiocyanate for treating mushroom substrates has been studied and is already applied in practice.

In a series of papers the influence of moisture content in substrate, substrate composition and other factors on yields of oyster mushroom $P$. ostreatus and $F$. velutipes was observed (Jablonský 1974, etc.). The fruiting of $P$. ostreatus has also been investigated in substrates with various carbon dioxide concentrations (Schánĕl et al. 1974).

Considerable attention has been paid to the study of mushroom diseases at the Mycological Station. The effect of allylisothiocyanate on germination of virus-containing basidiospores of $A$. bisporus has been investigated in order to examine its possible application against virus diseases of mushroom cultures, for instance by treating cultures before their 
termination (Juzlova et al. 1974). At the beginning of 1971, already, a method for protection of mushroom cultures with benomyl against cobweb (mildew:

Dactylium dendroides), bubble (Mycogone perniciosa) and verticilliosis (Verticillium malthousei) has been used with success (Staněk 1971).

\section{$\underline{\text { References }}$}

Esser; K., Semerdžieva, M. \& Stahl, U. 1974:

- Theoretical and Applied Genetics 45: 77-83. Jablonský, I. 1974: - In: Physiology, Ecology and Cultivation of Edible Fungi, Int. Symp., ČsSR, May 13-18 1974, pp. 45-46.
Juzlová, D., Stanĕk, M. \& Řehoř, J. 1974: - In: Physiology, Ecology and Cultivation of Edible Fungi, Int. Symp., CSSR, May 13-18 1974, p. 48.

Schánēl, L., Kozlík, L. \& Jablonský, I. 1974: - In: Physiology, Ecology and Cultivation of Edible Fungi, Int. Symp., CSSR, May 13-18 1974, pp. 15-16.

Stanĕk, M. 1971: - Pĕstování žampiónu (Mushroom Growing - Appendix of Mykologický sborñík) 8: 33-47.

-"- 1976: - Der Champignon 16 (174): 10-20.

-"- 1978: Micro-organisms and cultivated edible fungi. - Karstenia 18 (suppl.). (This issue).

Stanĕk, M. \& Konštantová, H. 1971: - Pěstovăn žampiónu (Mushroom Growing - Appendix of Mykologický sborǹík) 8: 91-95. 